\title{
Blood metabolic profile and acid base status of lactating Travnik ewes in an extensive production system
}

\author{
Zvonko Antunović1, Boro Miočㄹ, Željka Klir Šalavardić1*, Ivan Širićé, Valentino Držaićc, \\ Mislav Đidara ${ }^{1}$, Vatroslav Šrerić ${ }^{3}$, and Josip Novoselec ${ }^{1}$
}

${ }^{1}$ Faculty of Agrobiotechnical Sciences Osijek, Josip Juraj Strossmayer University of Osijek, Osijek, Croatia

${ }^{2}$ Department of Animal Science and Technology, Faculty of Agriculture, University of Zagreb, Zagreb, Croatia

${ }^{3}$ Department of Clinical Laboratory Diagnostics, University Hospital Osijek, Osijek, Croatia

ANTUNOVIĆ, Z., B. MIOČ, ̌̌. KLIR ŠALAVARDIĆ, I. ŠIRIĆ, V. DRŽAIĆ, M. ĐIDARA, V. ŠERIĆ, J. NOVOSELEC: Blood metabolic profile and acid base status of lactating Travnik ewes in an extensive production system. Vet. arhiv 91, 603-614, 2021.

\section{ABSTRACT}

The research aimed to determine the blood metabolic profile and acid-base status of lactating Travnik ewes in an extensive production system. The research was carried out on 108 lactating Travnik ewes, with an average age of 3-4 years, in their $3^{\text {rd }}$ lactation. The ewes were kept on pasture, and had water and animal salt ad libitum. Hematological indicators were determined in whole blood, biochemical parameters in serum, and acid-base status was determined in plasma. The determined average values of hematological parameters were mostly within reference values, except the lower MCHC content and higher MCV content, which indicates the instability of erythrocyte constants. Average mineral concentrations were within the reference values, except for $\mathrm{Ca}$ and Fe concentrations which were lower and were influenced by higher milk excretion. Most of the biochemical indicators, enzyme activity, and indicators of the acid-base balance of lactating Travnik ewes' blood were within the reference values. A high concentration of urea above the reference values was found, and concentrations of total proteins, albumins, total cholesterol, HDL and LDL cholesterol, and triglycerides at the upper limit or above the reference values were determined. Slightly lower GPx activity and higher SOD activity above reference values were determined. These indicators point to energy deficit, as well as poor grazing quality, and a lack of selenium in pasture plant species. When determining the blood metabolic profile of lactating Travnik ewes, the obtained results of the research should be considered, and they should be included in the development of reference values for the Travnik sheep breed.

Key words: Travnik ewes; hematological indicators; biochemical indicators; acid-base indicators; extensive production system

\section{Introduction}

With a significant increase in production per head in livestock production, there is an exceptional burden on animals, which makes it difficult to maintain stable physiological conditions (homeostasis) in their body and leads to the emergence of productional diseases (ANTUNOVIĆ et al., 2013). The term "metabolic profile" refers to the analysis of blood biochemical constituents that

\footnotetext{
*Corresponding author:

Assist. Prof. Željka Klir Šalavardić, PhD, Faculty of Agrobiotechnical Sciences Osijek, Josip Juraj Strossmayer University of Osijek, Vladimira Preloga 1, 31000 Osijek, Croatia, Phone: +385 31554 906, E-mail: zklir@fazos.hr
} 
are useful to evaluate and prevent metabolic and nutritional problems in dairy herds (ROSSATO et al., 2001; PUPPEL and KUCZYŃSKA, 2016). The development of laboratory equipment and computer programs that enable fast and efficient blood analysis and easier statistical processing of the obtained values of the analyzed indicators in the blood has contributed to the increasing use of metabolic profiles in animal husbandry. In addition to monitoring body weight and determining the body's condition score (BCS), it is possible to determine certain hematological and biochemical indicators, and in recent years indicators of acid-base balance in the blood more accurately determine the nutritional and health status of sheep (ANTUNOVIĆ etal., 2015). From the hematological indicators, the number of erythrocytes, leukocytes, and thrombocytes is most often determined, as well as hemoglobin concentration and hematocrit value, mean corpuscular volume (MCV), mean corpuscular hemoglobin $(\mathrm{MCH})$, and mean corpuscular hemoglobin concentration (MCHC). The proportion of individual white cells (lymphocytes, neutrophils, eosinophils, monocytes, and basophils) is determined from blood smears. The biochemical indicators most often determined in the blood are concentrations of minerals, glucose, urea, total protein, albumin, globulin, triglycerides, cholesterol, non-esterified fatty acids (NEFA), betahydroxybutyrate (BHB), and the activity of the enzymes alanine aminotransferase (ALT), aspartate aminotransferase (AST), alkaline phosphatase (ALP), gamma-glutamyl transferase (GGT), and creatine kinase $(\mathrm{CK})$.

Determining the metabolic profile is especially significant in grazing ewes where it is very difficult to know and monitor the consumption and chemical composition of the ration. This often leads to various nutrient deficiencies in rations that affect the quality of sheep productivity. The case of Mediterranean countries is often mentioned where ewes graze on poor quality pastures for most of the year (ANTUNOVIĆ et al., 2015, 2019). Determination of the metabolic profile is important in physiologically stressful periods for the animal (high pregnancy, lactation, especially early lactation) which impose severe metabolic changes that challenge the organism's maintenance of homeostatic equilibrium to compensate for the major expenditure of nutrients that lactogenesis demands (DRACKLEY, 1999; VAN SAUN, 2006, 2016, VAŽIĆ et al., 2020).

The concentrations of the studied indicators in the blood are influenced by several factors that can be divided into genetic (genotype, i.e. breed and sex of the animal) and non-genetic (nutrition, season, age of the animal, health status, reproductive status, breeding conditions, handling of samples during transport and storage, methods of determination) which have been confirmed in numerous studies with sheep (ANTUNOVIĆ et al., 2002, 2004, 2011, 2017a, 2017b; DURAK et al., 2015; CALPEREYRA et al., 2014; CARLOS et al., 2015; BRONDANI et al., 2016; OLIVEIRA et al., 2016; PESÁNTEZ-PACHECO et al., 2019). According to VAN SAUN (2000), concentrations of albumin, total protein, calcium, sodium, magnesium, phosphorus, potassium, chlorine, and NEFA have low variability and high diagnostic value, and cholesterol, urea, glucose, and BHB concentrations have medium variability and medium diagnostic significance, while liver enzymes, and creatine kinase activities have high variability and low diagnostic value. The study of the acid-base balance can provide information for the diagnosis and prognosis of various diseases. The most commonly observed type of acid-base disorder is metabolic acidosis (KANEKO et al., 2008; NOVOSELEC et al., 2013). A quality metabolic profile indicates the need to determine blood parameters distributed by region as well as genotype (breed). Namely, SHEK VUGROVEČKI et al. (2017) point out that the blood reference values of various sheep from the available literature are orientational but not adequate for the specific indigenous breeds in their natural habitat. Travnik sheep (dubska, vlašićka) are a breed of sheep originating from Bosnia and Herzegovina, and in the Republic of Croatia they are bred in the western part. Breeders of Travnik sheep, in addition to the production of lambs (meat), produce milk that is processed into cheese. Breeding of Travnik sheep is most often of extensive or semi-intensive character, where the only food is grazing. Travnik sheep belong to a larger population of sheep called 
Pramenka, they are late maturing and achieve full physical development between the third and fourth year of life. The body weight of ewes ranges from 60 to $70 \mathrm{~kg}$, and rams from 80 to $100 \mathrm{~kg}$ according to the Croatian Agricultural Agency (CAA, 2018). Sheep fertility is very good, about $130 \%$. Travnik sheep in lactation give about 70 to 1301 of milk, which emphasizes their good potential for milk, which undoubtedly can and should be improved (NOVOSELEC et al., 2020). Lactation itself is a highly demanding physiology process that utilizes a large amount of energy. Given the fact that these sheep graze on poor quality pastures for most of the year, in lactation, especially early lactation, the sheep cannot meet the requirements imposed by the onset of lactation accompanied by reduced feed intake. Consequently, there is a negative energy balance and the highest incidence of disease in high-producing sheep. Therefore, it is necessary to notice the expected problem and to take preventive actions. In that sense, there is a need to create a metabolic profile as a quality preventive measure in preserving the quality of rations and the health of the sheep. There are no data in the available literature on the complete metabolic profile of Travnik sheep, except for the study by HRKOVIĆ-POROBIJA et al. $(2017,2019)$ where several indicators in the blood of this breed in Bosnia and Herzegovina were investigated. This paper aims to determine the complete metabolic profile of lactating Travnik sheep in extensive breeding through determination of hematological, biochemical, and acid-base indicators, which will help us understand their nutritional and health status.

\section{Materials and methods}

Analyses of the metabolic blood profile of Travnik ewes were undertaken on 108 lactating Travnik ewes with an average age of 4 years in an extensive production system. Ewes were selected from the flock of 1000 animals on the basis of being in the third lactation and having only one lamb in the litter. The selected ewes were healthy and in good physical condition. The average body weight of the ewes was $53.58 \mathrm{~kg} \pm 7.11$. The body condition scores $(\mathrm{BCS})$ of the ewes $(1=$ emaciated to $5=$ obese) were evaluated by two trained technicians according to RUSSEL (1991) and the mean was $2.69 \pm 0.52$. Water and animal salt were offered to the ewes ad libitum. The present study was conducted in 2019 on a family farm located in Velika Peratovica, $10 \mathrm{~km}$ from Grubišno polje (in

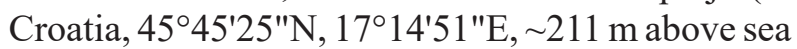
level). The monthly mean temperature for this area from May to July in 2019 was $19^{\circ} \mathrm{C}$ while the mean monthly rainfall was $113 \mathrm{~mm}$. Feed samples (green forage from pastures) were taken before the sheep went out to pasture, and dried and ground into a fine powder using a heavy metal free ultra-centrifugal mill (Retsch ZM 200) or knife mill (GM 200). Feed chemical composition was determined by standard methods (AOAC, 2006) and is presented in Table 1.

Table 1. Chemical composition of the ingredients in the lactating ewes' diets

\begin{tabular}{|l|c|}
\hline Parameters (g/kg DM) & Green forage \\
\hline Crude proteins & 196.83 \\
\hline Crude fiber & 168.70 \\
\hline Crude ash & 87.03 \\
\hline Ether extract & 26.10 \\
\hline NDF, $\%$ & 43.67 \\
\hline ADF, $\%$ & 24.69 \\
\hline Digestible energy, $\mathrm{MJ} \mathrm{kg}^{-1} \mathrm{DM}$ & 2.28 \\
\hline Metabolizable energy, $\mathrm{MJ} \mathrm{kg}^{-1} \mathrm{DM}$ & 1.98 \\
\hline Mineral content $\left(\mathrm{mg} / \mathrm{kg} \mathrm{DM}^{\mathrm{D}}\right)$ & \\
\hline $\mathrm{Ca}$ & 7706.10 \\
\hline $\mathrm{Mg}$ & 2373.61 \\
\hline $\mathrm{K}$ & 44589.98 \\
\hline $\mathrm{P}$ & 5568.33 \\
\hline $\mathrm{Na}$ & 116.96 \\
\hline $\mathrm{Fe}$ & 236.27 \\
\hline $\mathrm{Se}$ & 0.06 \\
\hline
\end{tabular}

DM - dry matter; NDF - neutral detergent fiber, ADF - acid detergent fiber

For determination of the Crude protein content (CP) in feed samples the Kjeldahl method was used, while ether extract (EE) was determined by using a Universal Extractions System B-811 (Buchi, Switzerland). Ash was determined by incinerating the feed samples at $550{ }^{\circ} \mathrm{C}$ for 6 hours. The determination of amylase-treated NDF 
was determined according to EN ISO 1647:2006 (European Committee for Standardization, 2006), while acid detergent fiber (ADF) was determined according to EN ISO 13906 (European Committee for Standardization, 2008). The digestible and metabolizable energy of feed for ewes was estimated according to DLG (1993). Feed samples were digested with $10 \mathrm{~mL}$ of a $5: 1$ mixture of $\mathrm{HNO}_{3}$ and $\mathrm{H}_{2} \mathrm{O}_{2}$ at $180{ }^{\circ} \mathrm{C}$ for $60 \mathrm{~min}$ in a microwave oven (CEM Mars 6). The concentrations of minerals in solutions of digested plant samples were determined by inductively coupled plasma (ICP, PerkinElmer Optima 2100 DV). Each batch of all samples run on the ICP was analyzed with an internal pooled plasma control, and with the reference material prepared in the same way as all the other samples. All samples were analyzed in duplicate.

From each lactating ewe, before grazing, blood samples were collected from the jugular vein $(10 \mathrm{~mL})$ into sterile vacuum Venoject ${ }^{\mathbb{B}}$ tubes (Sterile Terumo Europe, Leuven, Belgium). For hematology analysis blood was collected in tubes containing ethylenediamine tetra-acetic acid (EDTA) as anticoagulant. The EDTA tubes were inverted several times to ensure adequate mixing of the blood with the anticoagulant. Determination of hematological parameters (number of leukocyte WBC, erythrocytes - RBC and platelet - PLT, the content of hemoglobin - HGB, hematocrit - HCT, mean corpuscular volume - MCV, mean corpuscular hemoglobin - $\mathrm{MCH}$, and mean corpuscular hemoglobin concentration - MCHC) in the whole blood of the sheep was carried out on an automatic Sysmex PocH-100iV three differential hematology analyzer (Sysmex Europe GmbH, Hamburg, Germany). A differential blood test was carried out by a microscope using the prepared blood smears colored by Pappenheim. Afterward, blood samples collected in sterile Venoject ${ }^{\circledR}$ vacuum tubes (Sterile Terumo Europe, Leuven, Belgium) were centrifuged at $1609.92 \mathrm{~g}$ for $10 \mathrm{~min}$, and the obtained serum samples were placed into the Olympus AU400. In serum, the concentration of calcium, phosphorusinorganic, potassium, sodium, magnesium, iron, chloride, urea, glucose, total proteins (TP), albumin, cholesterol, high-density lipoprotein (HDL) cholesterol, low-density lipoprotein (LDL) cholesterol, triglycerides (TGC), $\beta$-hydroxybutyrate (BHB) and non-esterified fatty acids (NEFA), as well as activities of enzymes: alanine aminotransferase (ALT), aspartate aminotransferase (AST), alkaline phosphatase (ALP), creatine kinase (CK) and $\gamma$-glutamyl transferase (GGT) were measured using Olympus System reagents (Olympus Diagnostic $\mathrm{GmbH}$, Lismeehan, Ireland). Globulin content was calculated as the difference between total protein and albumin. The activity of glutathione peroxidase (GPx) in the serum was determined using a Ransel ${ }^{\circledR}$ kit (Randox, UK) on an automatic Olympus AU 400 (Olympus, Japan) analyzer on a wavelength of $240 \mathrm{~nm}$. The activity of total superoxide dismutase (SOD) in the serum was determined with a Ransod ${ }^{\circledR}$ kit (Randox, UK) on an automatic analyzer (Olympus AU 400, Olympus, Japan) at a wavelength of $510 \mathrm{~nm}$. Samples of plasma were obtained from sterile vacuum tubes containing Li-heparin and analyzed by a Rapid Lab 348automatic analyzer, which works on the basis of ion-selective electrodes. The following parameters were determined: $\mathrm{pH}$, the partial pressure of carbon dioxide (pCO2), the partial pressure of oxygen (pO2), the total pressure of carbon dioxide ( $\mathrm{tCO} 2)$, actual base excess-Cbase(B), standard base excess-Cbase(Ecf), oxygen saturation $(\mathrm{sO} 2)$ and bicarbonate (HCO3-). The Committee for Animal Welfare of the Faculty of Agrobiotechnical Sciences, Osijek, established that the research was being carried out under the legal provisions according to the Animal Protection Act (Official Gazette No. 133 of 2006, No. 37 of 2013 and No. 125 of 2013). Animal care and the conditions of the research followed the recommendations of European Union directive 2010/63/EU (European Commission, 2010). The distribution of data was verified by the Shapiro-Wilk test (PROC UNIVARIATE). The results of sheep's blood in a concentration of hematological, biochemical, and acid-base parameters were performed by the MEANS procedure. The results were presented as mean, min and max values, standard deviation, and standard error of mean. All data were analyzed with the statistical software SAS 9.4 ${ }^{\circledR}$. 


\section{Results}

The established average values of hematological parameters were mostly in an accordance with the reference values for sheep. However, lower mean values were found for MCHC content and higher for MCV content.
By analyzing the data from Table 3 it is visible that the mineral concentrations obtained were within the reference values for sheep, except for the concentrations of $\mathrm{Ca}, \mathrm{Na}$, and $\mathrm{Fe}$ which were lower, and $\mathrm{Cl}$ was higher.

Table 2. Hematological parameters and leukocyte distribution from lactating Travnik ewes

\begin{tabular}{|l|c|c|c|c|c|c|}
\hline & Mean & Min & Max & SD & SEM & Reference values* \\
\hline WBC $\left(\times 10^{9} \mathrm{~L}\right)$ & 8.06 & 3.20 & 18.70 & 3.05 & 0.29 & $4-12$ \\
\hline RBC $\left(\times 10^{12} \mathrm{~L}\right)$ & 9.53 & 7.01 & 13.03 & 1.29 & 0.12 & $9-15$ \\
\hline $\mathrm{HGB}(\mathrm{g} / \mathrm{L})$ & 107.73 & 77.00 & 170.00 & 15.85 & 1.53 & $90-150$ \\
\hline $\mathrm{HCT}(\mathrm{L} / \mathrm{L})$ & 0.39 & 0.26 & 0.57 & 0.06 & 0.006 & $0.27-0.45$ \\
\hline $\mathrm{MCV}(\mathrm{fL})$ & 40.24 & 35.40 & 48.50 & 2.40 & 0.23 & $28-40$ \\
\hline MCH $(\mathrm{pg})$ & 11.30 & 10.20 & 13.80 & 0.68 & 0.07 & $8-12$ \\
\hline MCHC $(\mathrm{g} / \mathrm{L})$ & 281.27 & 225.00 & 386.00 & 28.69 & 2.76 & $310-340$ \\
\hline PLT $\left(\times 10^{9} \mathrm{~L}\right)$ & 422.25 & 77.00 & 809.00 & 171.54 & 16.51 & $250-750$ \\
\hline \multicolumn{7}{|l|}{} \\
\hline Leukocyte distribution $(\%)$ & 56.46 & 31.00 & 87.00 & 12.10 & 1.16 & $40-75^{1}$ \\
\hline Lymphocytes & 35.30 & 11.00 & 65.00 & 11.62 & 1.12 & $10-50^{1}$ \\
\hline Neutrophils & 0.32 & 0.00 & 7.00 & 0.83 & 0.08 & $0-6^{1}$ \\
\hline Monocytes & 7.75 & 0.00 & 28.00 & 7.13 & 0.69 & $0-10^{1}$ \\
\hline Eosinophils & 0.18 & 0.00 & 2.00 & 0.43 & 0.04 & $0-3^{1}$ \\
\hline Basophils &
\end{tabular}

*Smith (2002); ${ }^{1}$ Kramer (2000); SD- standard deviation; SEM- standard error of mean; WBC-number of leukocytes, RBCerythrocytes, HGB-hemoglobin, HCT-hematocrit, MCV-mean corpuscular volume, MCH- mean corpuscular hemoglobin, MCHCmean corpuscular hemoglobin concentration; PLT - platelet count

Table 3. Blood minerals concentrations of lactating Travnik ewes $(\mathrm{mmol} / \mathrm{L})$

\begin{tabular}{|l|c|c|c|c|c|c|}
\hline & Mean & Min & Max & SD & SEM & Reference values* \\
\hline $\mathrm{Ca}$ & 2.52 & 1.72 & 3.07 & 0.28 & 0.03 & $2.88-3.20$ \\
\hline $\mathrm{P}$ & 1.85 & 1.14 & 3.30 & 0.39 & 0.04 & $1.62-2.36$ \\
\hline $\mathrm{Na}$ & 131.22 & 107.00 & 146.00 & 11.02 & 1.33 & $139-152$ \\
\hline $\mathrm{K}$ & 5.35 & 3.05 & 8.50 & 1.91 & 0.41 & $3.90-5.40$ \\
\hline $\mathrm{Mg}$ & 1.09 & 0.77 & 1.54 & 0.14 & 0.02 & $0,90-1,31$ \\
\hline $\mathrm{Cl}$ & 111.68 & 100.00 & 139.00 & 9.16 & 1.10 & $95.0-103.0$ \\
\hline $\mathrm{Fe}(\mu \mathrm{mol} / \mathrm{L})$ & 24.42 & 7.70 & 41.00 & 6.48 & 0.62 & $29.70-39.7$ \\
\hline
\end{tabular}

*Kaneko et al (2008); SD- standard deviation; SEM-standard error of mean 
Z. Antunović et al.: Blood metabolic profile and acid base status of lactating Travnik ewes in an extensive production system

Table 4. Blood biochemical parameters of lactating Travnik ewes (mmol/L)

\begin{tabular}{|l|c|c|c|c|c|c|}
\hline & Mean & Min & Max & SD & SEM & Reference values* \\
\hline Glucose & 4.05 & 2.32 & 8.96 & 1.09 & 0.10 & $2.78-4.44$ \\
\hline Urea & 9.97 & 1.17 & 16.21 & 2.07 & 0.20 & $2.86-7.14$ \\
\hline Total proteins $(\mathrm{g} / \mathrm{L})$ & 79.33 & 62.20 & 99.40 & 8.04 & 0.77 & $60.0-79.0$ \\
\hline Albumin $(\mathrm{g} / \mathrm{L})$ & 30.22 & 23.30 & 36.20 & 2.24 & 0.22 & $24-30$ \\
\hline Globulin $(\mathrm{g} / \mathrm{L})$ & 49.11 & 34.70 & 68.40 & 7.06 & 0.68 & $35-57$ \\
\hline CHOL & 2.01 & 1.02 & 3.03 & 0.38 & 0.04 & $1.35-1.97$ \\
\hline HDL & 1.36 & 0.96 & 1.94 & 0.21 & 0.02 & $1.09-1.18^{1}$ \\
\hline LDL & 0.58 & 0.23 & 1.15 & 0.20 & 0.02 & $0.36-0.40^{1}$ \\
\hline TGC & 0.25 & 0.12 & 0.47 & 0.09 & 0.01 & $0.0-0.2$ \\
\hline NEFA & 0.23 & 0.02 & 1.46 & 0.28 & 0.03 & $<0.4^{2}$ \\
\hline BHB & 0.34 & 0.16 & 0.55 & 0.09 & 0.01 & $<0.8^{3}$ \\
\hline
\end{tabular}

*Kaneko et al (2008); ${ }^{1}$ Antunovic et al. (2011); ${ }^{2}$ Oetzel (2004); ${ }^{3}$ Russel (1984); SD - standard deviation; SEM-standard error of mean; CHOL - cholesterol, TGC - triglycerides, BIL - bilirubin; NEFA - non-esterified fatty acids, BHB - $\beta$-hydroxybutyrate

Table 5. Blood enzymes activities of lactating Travnik ewes (U/L)

\begin{tabular}{|l|c|c|c|c|c|c|}
\hline & Mean & Min & Max & SD & SEM & Reference values* \\
\hline AST & 156.70 & 13.20 & 1188.80 & 105.46 & 10.19 & $60-280$ \\
\hline ALT & 23.74 & 12.30 & 38.00 & 5.51 & 0.53 & $22-38^{1}$ \\
\hline ALP & 181.56 & 54.90 & 508.90 & 112.35 & 10.81 & $50-300$ \\
\hline GGT & 56.66 & 19.80 & 118.40 & 15.14 & 1.46 & $40-94$ \\
\hline CK & 187.69 & 63.00 & 2251.00 & 263.82 & 25.39 & $35-280$ \\
\hline SOD, U/mL & 0.31 & 0.14 & 1.28 & 0.14 & 0.01 & $0.184^{2}$ \\
\hline GPx & 241.63 & 4.73 & 961.26 & 230.60 & 25.16 & $>600^{3}$ \\
\hline
\end{tabular}

*Smith (2002); ${ }^{1}$ Jackson and Cockcroft (2002); ${ }^{2}$ Maan et al. (2013); ${ }^{3}$ Pavlata et al. (2012) - whole blood; SD - standard deviation; SEM - standard error of mean; AST - aspartate aminotransferase, ALT - alanine aminotransferase, ALP - alkaline phosphatase, GGT - $\gamma$-glutamyl transferase, CK - creatine kinase, SOD - superoxide dismutase, GPx - glutathione peroxidase

Table 6. Blood acid-base balance of lactating Travnik ewes

\begin{tabular}{|l|c|c|c|c|c|c|}
\hline & Mean & Min & Max & SD & SEM & Reference values* \\
\hline $\mathrm{pH}$ & 7.33 & 7.25 & 7.37 & 0.06 & 0.01 & $7-32-7.54$ \\
\hline $\mathrm{pCO}_{2}, \mathrm{kPa}$ & 7.71 & 5.80 & 12.80 & 1.35 & 0.22 & $6.19^{1}$ \\
\hline $\mathrm{pO}_{2}, \mathrm{kPa}$ & 8.81 & 5.40 & 20.20 & 2.79 & 0.45 & $6.12^{1}$ \\
\hline $\mathrm{HCO}_{3}, \mathrm{mmol} / \mathrm{L}$ & 22.79 & 15.90 & 28.80 & 2.99 & 0.48 & $20-25$ \\
\hline $\mathrm{ctCO}_{2}, \mathrm{mmol} / \mathrm{L}$ & 24.63 & 17.20 & 30.80 & 3.13 & 0.50 & $21-28$ \\
\hline $\mathrm{Cbase}(\mathrm{B}), \mathrm{mmol} / \mathrm{L}$ & -4.73 & -9.30 & 1.40 & 3.07 & 0.49 & $-1.15^{1}$ \\
\hline $\mathrm{Cbase}(\mathrm{Ecf}), \mathrm{mmol} / \mathrm{L}$ & -3.84 & -8.70 & 2.70 & 3.07 & 0.50 & - \\
\hline $\mathrm{sO}_{2 . \%}$ & 80.95 & 76.0 & 99.10 & 10.77 & 1.30 & $69.78^{1}$ \\
\hline
\end{tabular}

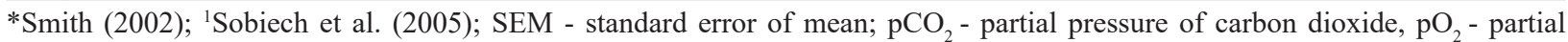
pressure of oxygen, $\mathrm{HCO}_{3}$ - bicarbonate, $\mathrm{ctCO}_{2}$ - total pressure of carbon dioxide, Cbase(B) - acutal base excess, Cbase(Ecf) standard base excess 
Average urea concentrations were notably higher, and albumin, total protein, total, HDL, and LDL cholesterol and triglyceride concentrations were at the upper limit or only slightly higher compared to their reference values for sheep (Table 4). Other biochemical parameters measured in the blood of Travnik ewes were within the reference values.

The activity of most enzymes in the blood of lactating Travnik ewes was within the reference values shown in Table 5. Significantly lower GPx activity and slightly higher SOD activity were found compared to the given reference limits of these enzymes for sheep.

The analysis of acid-base balance indicators in the blood did not reveal major deviations compared to the reference values.

\section{Discussion}

The basic rule that applies when determining the metabolic profile is that the mean value of the established indicators in the blood should preferably be in the middle of the reference values for sheep (VAN SAUN, 2000). The results of hematological and biochemical parameters of lactating Travnik ewes were within the reference values for sheep according to SMITH, 2002 and KANEKO et al., 2008. However, lower mean values were found for $\mathrm{MCHC}$ content and higher for MCV content. This indicates the instability of erythrocyte constants. VOJTA et al. (2011) found a similar number of RBCs and HGB and MCH content in the blood of Dalmatian sheep, as well as lower values of $\mathrm{MCV}$ and MCHC. Energy balance is a highly important nutritional factor that significantly affects the expression of productivity, reproduction, and animal health. For energy status analysis of lactating ewes, biochemical indicators such as NEFA, BHB, glucose cholesterol, and triglycerides in the blood were determined. Concentrations of glucose, NEFA, and BHB in the blood of lactating Travnik ewes were within the recommended range of values, but the concentrations of total, HDL and LDL cholesterol, and triglycerides were at the upper limit or slightly higher than the reference values for sheep (Table 3). Namely, triglyceride concentration uptake by the mammary gland for milk synthesis increased lipolysis, and decreased lipogenesis or limited liver capability to complete lipoproteins as the transportable form of triglycerides (MCART et al., 2013). The high blood cholesterol concentration during lactation arises because there is a strong reduction in lipogenesis, esterification, and an increase in the release of free fatty acids stimulated by catecholamine (epinephrine norepinephrine) (ZUMBO et al., 2007). The increase of triglycerides in the blood of lactating ewes was probably influenced by the negative energy balance that induces fat mobilization from adipose tissue.

Assessing the protein supply of animals is a more demanding and difficult procedure compared to assessing energy status. Therefore, a combination of different indicators in the blood is used, which includes determining the concentration of urea, creatinine, total protein, albumin, and creatine kinase activity. Liver function can be assessed by determining the activity of various enzymes (GGT, AST, ALT, SDH) and the concentration of total cholesterol, NEFA, BHB, and total bilirubin (VAN SAUN, 2000). Concentrations of urea above the reference value, and at the upper limit or slightly higher concentrations of total proteins and albumin indicate a ration rich in proteins. The blood parameters used to evaluate the protein status are total protein, albumins, and globulins, and this provides background information about protein biosynthesis, utilization, and excretion, as well as renal failure, liver damage, and nutritional health (ŠTOLCOVA et al., 2020). ALADROVIĆ et al. (2018) point out that the concentrations of albumin in the blood can be a quality indicator of the supply of feed proteins to animals. Blood urea concentrations are an indicator of the current supply of protein to animals through feed, while albumin concentrations are a good indicator over a longer period of time (more than a month). KOHN et al. (2005) presented that the concentration of urea can be considered as a good indicator of the amount of nitrogen consumed through feed. Also, the concentration of urea in the blood is an indicator of the proper energy supply to the animals. Similar changes of blood urea concentrations in Dubrovnik sheep on pasture during early lactation were observed by ANTUNOVIĆ et al. (2019). The 
finding that urea levels were notably above the reference values in the present study might indicate that these values should be considered in the future as a reference for this breed of sheep. Increased urea concentration in the blood of lactating ewes may be due to a lack of fermentable energy in the ration, so rumen microorganisms use ammonia to synthesize their proteins which can be further absorbed through the epithelium of the rumen into the blood and transported to the liver, where they are synthesized in urea. Higher concentrations of urea can be the result of pathological conditions but also other factors (lactation, season, heat stress, etc.). A high serum urea concentration may indicate increased ammonium detoxication and can be considered a risk factor for lipomobilization (PARK et al., 2010). VOJTA et al. (2011) found similar TP concentrations and GGT activity in Dalmatian sheep blood, as well as lower AST activity and cholesterol and urea concentrations. SHEK VUGROVEČKI et al. (2017), in a study on Lika sheep on pasture, also determined higher urea concentrations $(8.62 \mathrm{mmol} / \mathrm{L})$ in comparison with the reference values. Estimation of animal mineral supply is highly variable because most minerals in the animal organism are tightly regulated by the homeostatic mechanism. Therefore, the most common concentrations of minerals (especially macronutrients) in the blood are not taken as a replica of nutrition when the homeostatic system is functioning well (VAN SAUN, 2000). Lower concentrations of $\mathrm{Ca}, \mathrm{Fe}$, and $\mathrm{Na}$ in the blood of Travnik sheep in lactation might indicate increased excretion of $\mathrm{Ca}$ and $\mathrm{Fe}$ through milk, due to the increased milk production during early lactation (ANTUNOVIĆ et al., 2011). Namely, LIESEGANG et al. (2007) determined a lower concentration of $\mathrm{Ca}$ in ewes' blood after lambing and in early lactation, which might be associated with the increased secretion of $\mathrm{Ca}$ through the milk and its rearrangement in the bones. Rather, hypocalcemia may be symptomatic of inadequate pre- or postpartum feed intake (SEIFI et al., 2011). Significantly decreased Fe concentrations in the blood of Merinolandschaf sheep and Dubrovnik sheep in lactation were determined by ANTUNOVIĆ et al. (2017a, 2019). Markedly lower
GPx and slightly higher SOD activity was found in the present study compared to the reference values for sheep. This indicates a lack of selenium in the sheep's grazing, given the lack of this trace element in the soil in this area (POPIJAČ and PRPIĆMAJIĆ, 2002; ANTUNOVIĆ et al., 2010, 2020). Similar results for blood SOD $(0.234 \mathrm{U} / \mathrm{mL})$ were determined in Dubrovnik sheep by ANTUNOVIĆ et al. (2015). There is very little research on indicators of acid-base status in sheep. Generally, metabolic activity modifies the acid-base balance, although it is difficult to estimate the degree of its contribution to the metabolic component of acid-base balance (CASTILLO et al., 1998). In the present study, there was no deviation in the acid-base status indicators in the blood of sheep compared to the reference values for sheep. SOBIECH et al. (2005) determined similar $\mathrm{pH}$ values and $\mathrm{pCO} 2$, lower $\mathrm{sO} 2$, and higher content Cbase(B) in the venous blood of sheep. Animal nutrition is one of the important factors, and especially the nutritional cationic-anion balance, on which the acid-base balance in animal blood depends. Acid-base balance is an important homeostatic mechanism of the body because cellular enzymes act within narrow pH limits (NOVOSELEC et al., 2013). Therefore, the $\mathrm{pH}$ value in the blood of lactating ewes can be taken as a valuable indicator of acidbase balance, and it was within the reference values in the present research. CASTILLO et al. (1996) in a study on gravid sheep found a significant association between blood acid-base balance and energy metabolism. The authors concluded that lipid mobilization is a source of the production of strong metabolic acids, which leads the organism to change the acid-base balance towards metabolic acidosis. At the same time, the respiratory system responds to this by hyperventilation to excrete excess acids involved in this metabolism, thereby reducing $\mathrm{pCO}_{2}$, which was not the case in the present research. The concentration of bicarbonate ions $\left(\mathrm{HCO}_{3}^{-}\right)$in plasma depends on the saturation of hemoglobin with oxygen. The decrease in the concentration of hemoglobin in the tissues is accompanied by an increase in the concentration of $\mathrm{HCO}_{3}^{-}$in erythrocytes, which consequently passes through the cell membranes into the plasma (ADAMS et al., 1991). After that, the erythrocytes, 
together with the blood, travel to the lungs, where the reverse process takes place. Hemoglobin undergoes an oxygen enrichment process which increases its acidity, and as a result, a hydrogen ion is released which is neutralized by the $\mathrm{HCO}_{3}$ - anion, creating $\mathrm{CO}_{2}$ and $\mathrm{H}_{2} \mathrm{O}_{2}$, which are secreted by the alveolar air due to the increase in partial pressure. None of these processes were present in our case because the above indicators of acid-base balance were within the reference values.

\section{Conclusion}

On the basis of the results of the present study, it is evident that the extensive production system of Travnik sheep during the lactation period is satisfactory as all animals were healthy, but there is much room for improvement. When determining the metabolic profile of Travnik sheep, the fact should be considered that higher concentrations were determined of urea and lower concentrations of $\mathrm{Ca}$, $\mathrm{Fe}$, as well as lower activity of GPx in the blood compared to the reference values. This indicates the need to improve nutrition and include the changes in the concentrations of blood parameters identified in the development of reference values for the Travnik sheep breed.

\section{Conflict of interest}

The authors declare that they have no conflict of interest.

\section{Acknowledgements}

The study was carried out within the research team Innovative Breeding and Technological Processes in Animal Production (No. 1126) at the Faculty of Agrobiotechnical Sciences, Osijek.

\section{References}

ADAMS, R., M. D. HOLLAND, B. ALDRIDGE, F. B. Garry, K. G. Odde (1991): Arterial blood sample collection from the newborn calf. Vet. Res. Commun. 15, 387-394

DOI: 10.1007/BF00366996

ALADROVIĆ, J., M. PAVKOVIĆ, B. BEER-LJUBIĆ, L. VRANKOVIĆ, Z. STOJEVIĆ (2018): Monitoring the health of a herd of dairy cows of the Holstenstein breed with a test of metabolic profile. Veterinarska stanica 49, 9-18. (in Croatian)

ANTUNOVIĆ, Z., M. ŠPERANDA, Đ. SENČIĆ, B. LIKER (2002): Influence of the season and reproductive status of ewes on blood parameters. Small Ruminant Res. 45, 39-44. DOI: 10.1016/S0921-4488(02)00109-8.
ANTUNOVIĆ, Z., M. ŠPERANDA, Z. STEINER (2004): The influence of age and the reproductive status to the blood indicators of ewes. Arch. Tierz. Dummerstorf. 47, 265-273, DOI: $10.5194 / \mathrm{aab}-47-265$.

ANTUNOVIĆ, Z., ZD. STEINER, M. VEGARA, M. ŠPERANDA, ZV. STEINER, J. NOVOSELEC (2010): Concentration of selenium in soil, pasture, blood and wool of sheep. Acta Veterinaria (Beograd), 2-3, 263-271.

ANTUNOVIĆ, Z., J. NOVOSELEC, M. ŠPERANDA, M. VEGARA, V. PAVIĆ, B. MIOČ, M. DJIDARA (2011): Changes in biochemical and hematological parameters and metabolic hormones in Tsigai ewes blood in the first third of lactation. Archiv für Tierzucht. 54, 5, 535-545.

ANTUNOVIĆ, Z., J. NOVOSELEC, Ž. KLIR, M. ĐIDARA (2013): Hematological parameters in the Alpine goats during lactation. Poljoprivreda 19, 2, 40-43, 2013.

ANTUNOVIĆ, Z., B. MARKOVIĆ, J. NOVOSELEC, M. ŠPERANDA, M. MARKOVIĆ, B. MIOČ, M. ĐIDARA, Ž. KLIR, D. RADONJIĆ (2015): Blood metabolic profile and oxidative status of endangered Mediterranean sheep breeds during pregnancy. Bulg. J. Agric. Sci. 21, 655-661.

ANTUNOVIĆ, Z., J. NOVOSELEC, M. ŠPERANDA, Z. STEINER, S. ĆAVAR, N. PAVLOVIĆ, K. VALEK LENDIČ, B. MIOČ, N. PAĆINOVSKI, Ž. KLIR (2017a): Monitoring of blood metabolic profile and milk quality of ewes during lactation in organic farming. Mljekarstvo 67, 4, 243-252.

ANTUNOVIĆ, Z., J. NOVOSELEC, Ž. KLIR (2017b): Hematological parameters in ewes during lactation in organic farming. Poljoprivreda 23, 2, 46-52.

ANTUNOVIĆ, Z., I. MARIĆ, Ž. KLIR, B. MIOČ, J. NOVOSELEC (2019): The effect of concentrates on production traits, biochemical parameters and thyroid hormones concentration in Dubrovnik sheep fed forage based-diets. Vet. arhiv 89, 4, 505-518.

ANTUNOVIĆ, Z., B. MIOČ, Ž. KLIR, I. ŠIRIĆ, V. DRŽAIĆ, Z. LONČARIĆ, G. BUKVIĆ, J. NOVOSELEC (2020): Concentrations of mercury and other elements in ewes' milk: Effect of lactation stage. Chemosphere 261, 128128

DOI: $10.1016 /$ j.chemosphere.2020.128128.

ASSOCIATION OF OFFICIAL ANALYTICAL CHEMISTS (2006): Official Methods of Analysis of AOAC International. Association of Analytical Communities, Arlington, Virginia, USA.

BRONDANI, W. C., J. S. LEMES, O. G. L. FERREIRA, V. F. B. ROLL, F. A. B. DEL PINO (2016): Metabolic profile of sheep in pregnancy. Archivos de Zootecnia 65, 249, 107-113. DOI: 10.21071/az.v65i249.449

CROATIAN AGRICULTURAL AGENCY (2018): Annual Report. Sheep, Goats and Small Animals Breeding. Zagreb, p. 154.

CAL-PEREYRA, L., A. BENECH, J. R. GONZÁLEZMONTAÑA, J. ACOSTA-DIBARRAT, S. DA SILVA, 
A. MARTÍN (2014): Changes in the metabolic profile of pregnant ewes to an acute feed restriction in late gestation, New Zealand Veterinary Journal. 63, 3, 141-146.

DOI: 10.1080/00480169.2014.971083

CARLOS, M. M. L., J. H. G. M. LEITE, D. F. CHAVES, A. M. VALE, D. A. E. FACANHA, M. M. MELO, B. SOTOBLANCO (2015): Blood parameters in the Morada Nova sheep: influence of age, sex and body condition score. J. Anim. Plant Sci. 25, 4, 950-955.

CASTILLO, C., J. HERNANDEZ, I. AYALA, M. J. CANO, M. LOPEZ, E. GUINARTE, J. BENEDITO (1996): Increased lipid metabolism as a cause of variations in the acid-base balance in female sheep. In: Proceedings of the IV Congreso de la Federation Mediterranea de Sanidad y Produccion de Ruminates. Murcia, pp. 143-146 (in Spanish).

CASTILlO, C., J. HERNANDEZ, M. MIRANDA, M. LOPEZ, I. AYALA, J. L. BENEDITO (1998): Analysis of acid-base balance by appplication of Fencl's equations in sheep. J. Appl. Anim. Res. 14, 135.

DOI: 10.1080/09712119.1998.9706691.

DLG (1993): Feed Value Tables for Ruminants. 6 Auflage, Frankfurt am Main (in German).

DRACKLEY, J. K. (1999): Biology of dairy cows during the transition period: the final frontier. J. Dairy Sci. 82, 22592273.

DURAK, M. H., R. E. C. ERKAN, R. ÇELIK, B. YOKUŞ, D. KURT, S. GÜRGÖZE (2015): The effects of age and gender on some biochemical serum parameters in Zom sheep raised in the vinicity Karacadağ. Israel J. Vet. Med. 70, 2, 33-39.

EUROPEAN COMMITTEE FOR STANDARDIZATION (2006): Animal feeding stuffs-determination of amylasetreated neutral detergent fibre content (aNDF) (ISO 1647:2006; EN ISO 16472:2006). European Standard, Brussels, Belgium.

EUROPEAN COMMITTEE FOR STANDARDIZATION (2008): Animal feeding stuffs-determination of acid detergent fibre (ADF) and acid detergent lignin (ADL) contents (ISO 13906:2008). European standard, Brussels, Belgium.

EUROPEAN COMMISSION (2010): Directive 2010/63/ EU of the European Parliament and of the council of 22 September 2010 and of the council of 22 September 2010 on the protection of animals used for scientific purposes. Available at: http://eurlex.europa.eu/LexUriServ/ LexUriServ.do?uri = OJ:L:2010:276: 0033:0079:EN:PDF

HRKOVIĆ-POROBIJA, A., A. HODŽIĆ, R. ABRAHAMSEN, Z. SARIĆ, Ć. CRNKIĆ, M. VEGARA, N. HADZIMUSIC, A. RUSTEMPAŠIĆ (2017): Physiological characteristization of Dubska pramenka. Food and Nutrition Sciences 8, 465-473.

HRKOVIĆ POROBIJA, A., M. VEGARA, A. HODŽIĆ, E. PAŠIĆ-JUHAS, A. SOFTIĆ, H. OHRAN (2019): The influence of geographic area on blood parameters of
Pramenka Sheep in the area of Bosnia and Herzegovina. Turkish Journal of Veterinary Research 3, 1, 1-8.

JACKSON, P., P. COOCKCROFT (2002): Clinical Examination of Farm Animals. Wiley-Blackwell. p. 320.

KANEKO, J. J., J. W. HARVEY, M. L. BRUSS (2008): Clinical Biochemistry of Domestic Animals. $6^{\text {th }}$ ed. Elsevier/ Academic Press, Amsterdam. p. 931.

KOHN, R. A., M. M. DINNEEN, E. RUSSEK-COHEN (2005): Using blood urea nitrogen to predict nitrogen excretion and efficiency of nitrogen utilization in cattle, sheep, goats, horses, pigs and rats. J. Anim. Sci. 83, 879-889.

DOI: $10.2527 / 2005.834879 x$.

KRAMER, J. W. (2000): Normal hematology of cattle, sheep and goats. In: Schalm's Veterinary Hematology. $5^{\text {th }}$ ed. (Feldman, B. F., J. G. Zinkl, N. C. Jain, Eds). Philadelphia, Lippincott Williams \& Wilkins, pp. 1075-1084.

LIESEGANG, A., J. RISTELI, M. WANNER (2007): Bone metabolism of milk goats and ewes during $2^{\text {nd }}$ pregnancy and lactation in comparison to first lactation. Journal of Animal Physiology and Animal Nutrition. 91, 217-255.

DOI: 10.1111/j.1439-0396.2007.00695.x

MAAN, R., N. KATARIA, P. K. PILANIA, A. SHARMA, S. ARORA, A. JOSHI, L. N. SANKHALA, S. K. SHARMA, N. MOHAMMAD, P. NATHAWAT, A. K. KATARIA (2013): Superoxide dismutase profiling during extreme ambiences in Marwari sheep from arid tracts. Vet. Res. 6, $15-18$.

MCART, J. J. A., D. V. NYDAM, G. R. OETZEL, T. R. OVERTON, P. A. OSPINA (2013): Elevated non-esterified fatty acids and $\beta$-hydroxy-butyrate and their association with transition dairy cow performance. Vet. J. 198, 560570 .

NOVOSELEC, J., Z. ANTUNOVIĆ, M. ŠPERANDA, Ž. KLIR, M. ĐIDARA (2013): Bood acid-base balance in growing lambs. Krmiva. Časopis o hranidbi životinja, proizvodnji i tehnologiji krme 55, 123-128.

NOVOSELEC, J., I. GREGURINČIĆ, Ž. KLIR, B. MIOČ, I. ŠIRIĆ, V. DRŽAIĆ, Z. ANTUNOVIĆ (2020): The estimation of body weight from body measurements of Travnik Pramenka ewes in the area of Bilogora, Croatia. Journal of Central European Agricultural 21, 207-214.

DOI: /10.5513/JCEA01/21.2.2667

OETZEL, G. R. (2004): Monitoring and testing dairy herds for metabolic disease. Vet. Clin. North Am. Food Anim. Parct. 20, 651-674.

DOI: $10.1016 /$ j.cvfa.2004.06.006

OLIVEIRA R. P. M., R. T. ASSANTE, A. F. SILVA, F. F. OLIVEIRA, F. G. G. CRUZ, J. P. F. RUFINO (2016): Evaluation of metabolic profile at different stages of peripartum of Santa Inês ewes in the Western Amazon. Rev. Bras. Saúde Prod. Anim. 17, 37-44.

PARK, A. F., J. E SHIRLEY, E. C. TITGEMEYER, R. C. COCHRAN, J. M. DEFRAIN, E. E. WICKERSHAM, D. E. 
JOHNSON (2010): Characterization of plasma metabolite sin Holstein dairy cows during the periparturient period. Int. J. Sairy Sci. 5, 4, 253-263.

PAVLATA, L., L. MISUROVA, A. PECHOVA, T. HUSAKOVA R. DVORAK (2012): Direct and indirect assessment of seleniumstatusinsheep-acomparison. Vet.Med.57,219-223.

PESÁNTEZ-PACHECO, J. L., A. HERAS-MOLINA, L. TORRES-ROVIRA, M. V. SANZ-FERNÁNDEZ, C. GARCÍA-CONTRERAS, M. VÁZQUEZ-GÓMEZ, P. FEYJOO, E. CÁCERES, M. FRÍAS-MATEO, F. HERNÁNDEZ, P. MARTÍNEZ-ROS, J. V. GONZÁLEZMARTIN, A. GONZÁLEZ-BULNES, S. ASTIZ (2019): Maternal metabolic demands caused by pregnancy and lactation: association with productivity and offspring phenotype in high-yielding dairy ewes. Animals 9, 295.

DOI: 10.3390/ani9060295

POPIJAČ, V., D. PRPIĆ-MAJIĆ (2002): Soil and wheat grain selenium content in the vicinity of Koprivnica (Croatia). Arhiv za higijenu rada i toksikologiju 53, 125-133.

PUPPEL, K., B. KUCZYŃSKA (2016): Metabolic profiles of cow's blood; a review. Metabolic profiles of cow's blood; a review. J. Sci. Food Agric. 96, 13, 4321-4328.

DOI: $10.1002 /$ jsfa. 7779

ROSSATO, W., F. H. D. GONZÁlEZ, M. M. DIAS, D. RICCÓ, S. F. VALLE, V. L. L. ROSA, T. CONCEIÇÃO, F. DUARTE, V. WALD (2001): Number of lactations affects metabolic profile of dairy cows. Archives of Veterinary Science 6, 2, 83-88.

RUSSEL, A. (1984): Means of assessing the adequacy of nutrition of pregnant ewes. Livest. Prod. Sci., 11, 429-436.

RUSSEL, A. (1991): Body condition scoring of sheep. In: Sheep and goat practice. (Boden, E., Ed.). Bailliere Tindall, Philadelphia, USA, p. 3.

SAS 9.4 ${ }^{\circledR}$, SAS Institute Inc., Cary, NC, USA

SEIFI, H. A., S. J. LEBLANC, K. E. LESLIE, T. F. DUFFIELF (2011): Metabolic predictors of post-partum disease and culling risk in dairy cattle. Vet. J. 188, 216-220.

SHEK VUGROVEČKI, A., A. VOJTA, M. ŠIMPRAGA (2017): Establishing reference intervals for haematological and biochemical blood variables in Lika pramenka sheep. Vet. arhiv 87, 487-499.

DOI: $10.24099 /$ vet.arhiv.160314

SMITH, B. P. (2002): Large Animal. Internal Medicine, Copyright Mosby, Inc., p. 393.

SOBIECH, P., A. STOPYRA, Z. KULETA, M. ZBANYSZEK, S. MILEWSKI (2005): Acid-base balance parameters of arterial, venous and capillary blood in sheep. Bull Vet. Inst. Pulawy 49, 125-127.

ŠTOLCOVA, M., D. ŘEHÁK, L. BARTOŇ, R. RAJMON (2020): Blood biochemical parameters measured during the periparturient period in cows of holstein and Fleckvieh breeds differing in production purpose. Czech Journal of Animal Science. 65, 172-181.

VAN SAUN, R. J. (2000): Blood profiles as indicators of nutritional status. Department of Large Animal Clinical Sciences, College of Veterinary Medicine, Oregon State University, Corvallis, Oregon, USA, pp. 97331-4802.

VAN SAUN, R. J. (2006): Metabolic profiles for evaluation of the transition period. Proceedings of American Association of Bovine Practitioners. 39, 130-138.

VAN SAUN, R. J. (2016): Indicators of dairy coe transition risks: Metabolic profiling revisited. Tierärtzliche Praxis Großtiere 2, 118-125.

VOJTA, A., A. SHEK-VUGROVEČKI, L. RADIN, M. EFENDIĆ, J. PEJAKOVIĆ, M. ŠIMPRAGA (2011): Hematological and biochemical reference intervals in Dalmatian pramenka sheep estimated from reduced sample size by bootstrap resampling. Vet. arhiv 81, 1, 25-33.

VAŽIĆ, B., M. DRINIĆ, D. KASAGIĆ, S. POPADIĆ, B. ROGIĆ (2020): Metabolic profile of the blood of Simmental cows during a production cycle. Vet. arhiv 90, 11-18.

DOI: 10.24099/vet.arhiv.0371

ZUMBO, A., A. R. DI ROSA, S. CASELLA, G. PICCIONE (2007): Changes in some blood hematological parameters of Maltese goats during lactation. J. Anim. Vet. Adv. 6, 706-711. 
Received: 2 October 2020

Accepted: 7 October 2021

ANTUNOVIĆ, Z., B. MIOČ, Ž. KLIR ŠALAVARDIĆ, I. ŠIRIĆ, V. DRŽAIĆ, M. ĐIDARA, V. ŠERIĆ, J. NOVOSELEC: Metabolički profil krvi i acido-bazni status ovaca travničke pramenke u ekstenzivnom proizvodnom sustavu. Vet. arhiv 91, 603-614, 2021.

\section{SAŽETAK}

Cilj istraživanja bio je utvrditi metabolički profil krvi i acido-bazni status ovaca travničke pramenke u ekstenzivnom proizvodnom sustavu. Istraživanje je provedeno na 108 ovaca travničke pramenke prosječne dobi 3 - 4 godine, u trećoj laktaciji. Ovce su boravile na pašnjaku, a vodu i stočnu sol imale su ad libitum. Hematološki pokazatelji određeni su u punoj krvi, biokemijski pokazatelji u serumu, a acido-bazni status u plazmi. Utvrđene prosječne vrijednosti hematoloških pokazatelja bile su u najvećoj mjeri u fiziološkim granicama, osim manje prosječne vrijednosti MCHC-a te veće vrijednosti MCV-a, što upućuje na nestabilnost eritrocitnih konstanti. Prosječne koncentracije minerala bile su u granicama referentnih vrijednosti, osim koncentracija kalcija i željeza koje su bile manje, a pod utjecajem su većeg izlučivanja mlijekom. Većina biokemijskih pokazatelja, aktivnosti enzima i pokazatelja acido-bazne ravnoteže krvi ovaca travničke pramenke bila je u granicama referentnih vrijednosti. Treba naglasiti utvrđenu veću koncentraciju uree te na gornjoj granici ili veće od referentnih vrijednosti koncentracije albumina, ukupnih proteina, ukupnog kolesterola, HDL i LDL-kolesterola i triglicerida, kao i manju aktivnost GPx te nešto veću SOD-a. To upućuje na energetski deficit te kvalitetu paše i nedostatak selena. Pri utvrđivanju metaboličkog profila travničke pramenke u obzir treba uzeti rezultate dobivenih istraživanja te ih uvažavati pri izradi referentnih vrijednosti za ovu pasminu.

Ključne riječi: travnička pramenka; hematološki pokazatelji; biokemijski pokazatelji; acido-bazni pokazatelji; ekstenzivni proizvodni sustav 